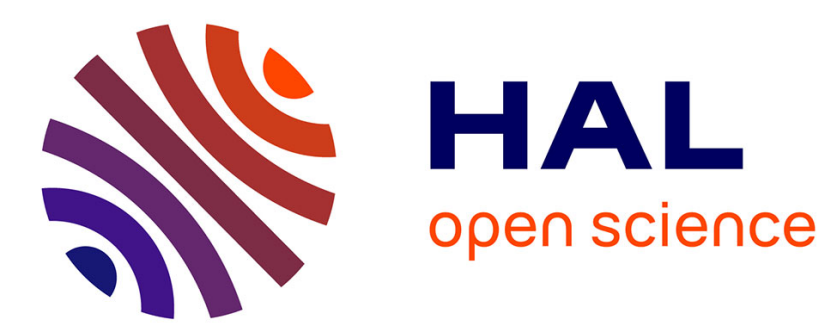

\title{
INTERNAL FRICTION OF HIGH DAMPING CAPACITY MANGANESE ALLOYS
}

\author{
I. Harangozó, L. Egri, F. Kedves, S. Kiss
}

\section{To cite this version:}

I. Harangozó, L. Egri, F. Kedves, S. Kiss. INTERNAL FRICTION OF HIGH DAMPING CAPACITY MANGANESE ALLOYS. Journal de Physique Colloques, 1983, 44 (C9), pp.C9-303-C9-306. 10.1051/jphyscol:1983942 . jpa-00223389

\section{HAL Id: jpa-00223389 https://hal.science/jpa-00223389}

Submitted on 1 Jan 1983

HAL is a multi-disciplinary open access archive for the deposit and dissemination of scientific research documents, whether they are published or not. The documents may come from teaching and research institutions in France or abroad, or from public or private research centers.
L'archive ouverte pluridisciplinaire HAL, est destinée au dépôt et à la diffusion de documents scientifiques de niveau recherche, publiés ou non, émanant des établissements d'enseignement et de recherche français ou étrangers, des laboratoires publics ou privés. 
Institute for Applied Physics, Kossuth L. University, Debrecen, P.O. Box 2, H-4010, Hungary

* Csepel Metal Works, Csepel 1, P.O. Box 49, H-1751, Hungary

Résumé - Le frottement intérieur/IF/ et sa dépendance de I'amplitude /ADIF/ sont étudiés dans divers alliages de haut amortissement $\mathrm{Mn} / 71 /-\mathrm{Cu}$ avec une addition du quantité faible de $\mathrm{Ni}$ ou/et $\mathrm{Si}$. Le IF et ADIF mesurés à température ambiante dans la région du déformation relative, $\varepsilon_{m}, 10.1-2 / \times 10-4$ diminuent avec le temps de vieillissement $/ 0.5^{-}-15 \mathrm{hrs} /$ à $450^{\circ} \mathrm{C}$. Ia diminution du ADIF dépend de la composition de l,alliage et de la durée du traitement termique préalable à $850^{\circ} \mathrm{C}$ fait avant le laminage à froid final. La présence simultanée de $\mathrm{Ni}$ et Si n'a pas augmenté za capacité spécifique dsamortissement /à $\mathcal{E}_{m}=$ $=10^{-4} /$ mais elle conduisait à grain fin après un court traitement termique préalable.

Abstract - The internal friction /IF/ and the amplitude dependence of it /ADIF/ were studied in different Mn/7I/-Cu high damping alloys with additionel small amounts of $\mathrm{Ni}$ or/and $\mathrm{Si}$. The IF and ADIF at room temperature measured in the relative deformation range, $\varepsilon_{m}, / 0.1-2 / \times 10^{-4}$ decrease with increasing ageing time $10.5-15^{\prime} \mathrm{hrs} /$ at $450^{\circ} \mathrm{C}$. The decrease of the ADIF depends on the composition and the length of the previous annealing time at $850^{\circ} \mathrm{C}$ performed before final cold rolling. The simultaneous presence of $\mathrm{Ni}$ and $\mathrm{Si}$ did not increase significantly the specific damping capacity /at $\varepsilon_{m}=10-4 /$ but led to much smaller grain sizes also with short previous annealing.

\section{Introduction}

High damping Mn-Cu alloys were studied intensively [1 - 10] because they possess high damping capacity /HDC/ being important for various applications besides their good mechanical properties [2]. This high damping capacity state /HDCS/ is associated with a metastable facecentred-tetragonal structure developed from the $r$-phase. When quenched from the $\gamma$ region the alloys containing $50-82$ wt\%lm have cubic structure but performing an ageing treatment $/ 400-6000 \mathrm{C} /$ the unit cells become tetragonal and simultaneously $\alpha$-lin precipitates appear along grain boundaries $[3,6]$. Maximal HDCS could have been achieved in a $\mathrm{Mn} / 75 \mathrm{wt \%} / \mathrm{Cu}$ alloy after an ageing at $400^{\circ} \mathrm{C}$ [10] when precipitates of $15-20 \mathrm{~nm}$ size having $\gamma_{\mathrm{K}-\mathrm{Mn}}$ structure have been formed and $\alpha, M n$ precipitates within the grain boundaries just appeared.

The HDCS can be affected by small amounts of third alloying elements leg. Fe Co,AI, Ga/ $[9,10]$, several of them /eg. Cu, Ni, Ga/ could be advantageous by stabilizing this state. The HDCS can be studied by measuring the intermal friction /IF/, the amplitude dependence of IF /ADIF/, the electrical resistivity, end different mechanical properties /eg. hardness, Young modulus/[1-10]. The height of IF is connected with the direct energy dissipation in the structure, the ADIF reflects the dislocation interaction with precipitates, phase boundaries and impurity atoms [11] . 
The purpose of the present work was to collect information on the $\mathrm{HDCS}$ of $\mathrm{Mn} / 7 \mathrm{wt} \% /-\mathrm{Cu}$ alloy and on the effect of small amounts of additional $\mathrm{Ni}$ and $\mathrm{Si}$.

\section{Experimental procedure}

The alloys /composition in Table $1 /$ were smelted in a vacuum induction furnace then cast and after appropriate cleaning cold rolled. A part of the series of every composition was annealed at $850^{\circ} \mathrm{C}$ for 10 hours in vacuum then cooled down there/marked by $\mathrm{H} /$. An other group of the samples was annealed also at $850^{\circ} \mathrm{C}$ but for $I$ hour and cooled down in air. All samples were then cold rolled dow to thickness of $1 \mathrm{~mm}$ and annealed again at $850^{\circ} \mathrm{C}$ for 2 hours in air and quenched in water.

A11 specimens of $75 \times 1 \times 1 \mathrm{~mm}^{3}$ size were aged at $450^{\circ} \mathrm{C}$ in air for different times and quenched in water. The IF measurements realizing in an inverted torsion pendulum at about $\mathrm{I} \mathrm{Hz}$ at room temperature / Rm/ were started several minutes after quenching. The micromorphology of the samples were investigated by transmission electron microscopy on electrolically thinned foils.

Table 1.

\begin{tabular}{|c|c|c|c|c|}
\hline \multirow{2}{*}{ Material } & \multicolumn{4}{|c|}{ Composition /wt\%l } \\
\hline & IIn & $\mathrm{Cu}$ & $\mathrm{Ni}$ & $\mathrm{Si}$ \\
\hline $\begin{array}{r}7 \\
8 \\
9 \\
10\end{array}$ & $\begin{array}{l}71 \\
72 \\
71 \\
72\end{array}$ & $\begin{array}{l}29 \\
26 \\
28.5 \\
25.5\end{array}$ & $\begin{array}{l}\overline{2} \\
\overline{2}\end{array}$ & $\begin{array}{l}- \\
\overline{0} .5 \\
0.5\end{array}$ \\
\hline
\end{tabular}

Results and Discussion

The IF was measured at RT in the $\varepsilon_{\mathrm{m}}$ range: $/ 0.1-2 / \times 10^{-4}$ on specimens aged for different time intervals $/ 0.5-15$ hours/. Typical results can be seen in Fig.1, where the ageing time/tage/ are indicated on the curves /0 means no ageing/. The position and the slope of each curve are characteristic to all specimens. The highest IF value is achieved after $t_{a g e}=0.5$ hours for all samples except those

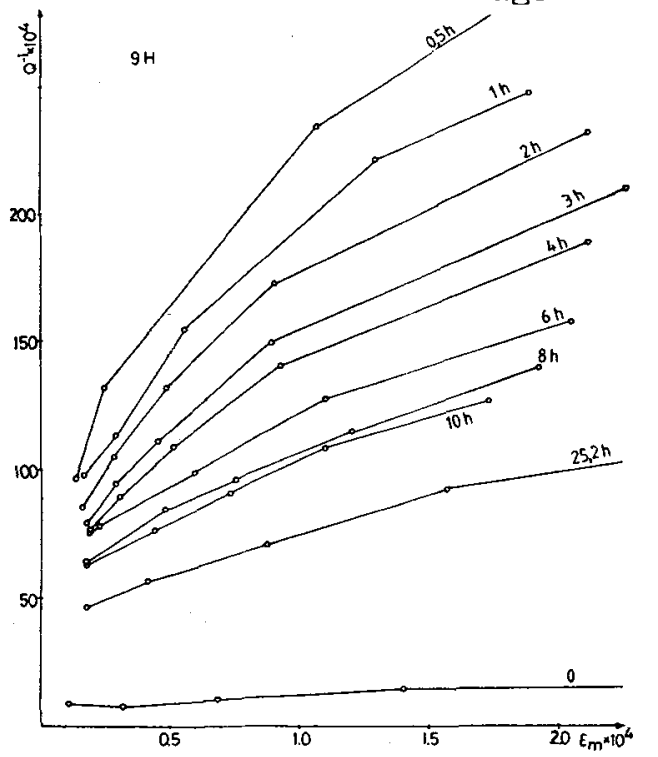
which do not contain Ni or Si. These specimens reached the highest IF value after $t_{a g e}=1$ hour. It has to be noted that all measurements have been performed in the amplitude dependent region. The IF value measuring below $\varepsilon_{\mathrm{m}}=10^{-6}$ at $\mathrm{RT}$ does not change on similar samples after being made an ageing at $450^{\circ} \mathrm{C}$ for $20 \mathrm{~min}$ [12].

We determined the specific damping capacity /SDC/ values from the IF data belonging to $\varepsilon_{\mathrm{m}}=10^{-4}$ relative deformation / Table 2/, which do not differ essentially from the values found in the literature [10]. The change in IF is also significant and characteristic but the absolute value of the damping is important. 
Table 2.

\begin{tabular}{|l|rrrrrrrr|}
\hline condition & 7 & $7 \mathrm{H}$ & 8 & $8 \mathrm{H}$ & 9 & $9 \mathrm{H}$ & 10 & $1 \mathrm{OH}$ \\
SDC $/ \% /$ & 17 & 15 & 12 & 13 & 10 & 14 & 15 & 13 \\
\hline
\end{tabular}

The choice of $\varepsilon_{m}$ is arbitrary and does not reflect the changes found, therefore we determined further characteristic parameters of the curves. It was found that for different $\varepsilon_{m}=$ const the $Q^{-1}$ vs log tage curves are straight lines /Fig. $2 /$. Such connection was found for each sample listed in Table 2. If we now plot the slopes of the straight lines/i.e. $\partial Q^{-I} / \partial I g$ ( $\left.t_{a g e} / \tau\right)$, where $\tau$ is the period of the vibration of the pendulum/ belonging to $\varepsilon_{m}=$ const we get again one straight line for each state $/$ Fig. $3 \%$ It can be seen in Fig. 3 that alloys 7 and 8 differ essentially in homogenized $/ \mathrm{H} /$ and not homogenized states but at the same time the difference be-
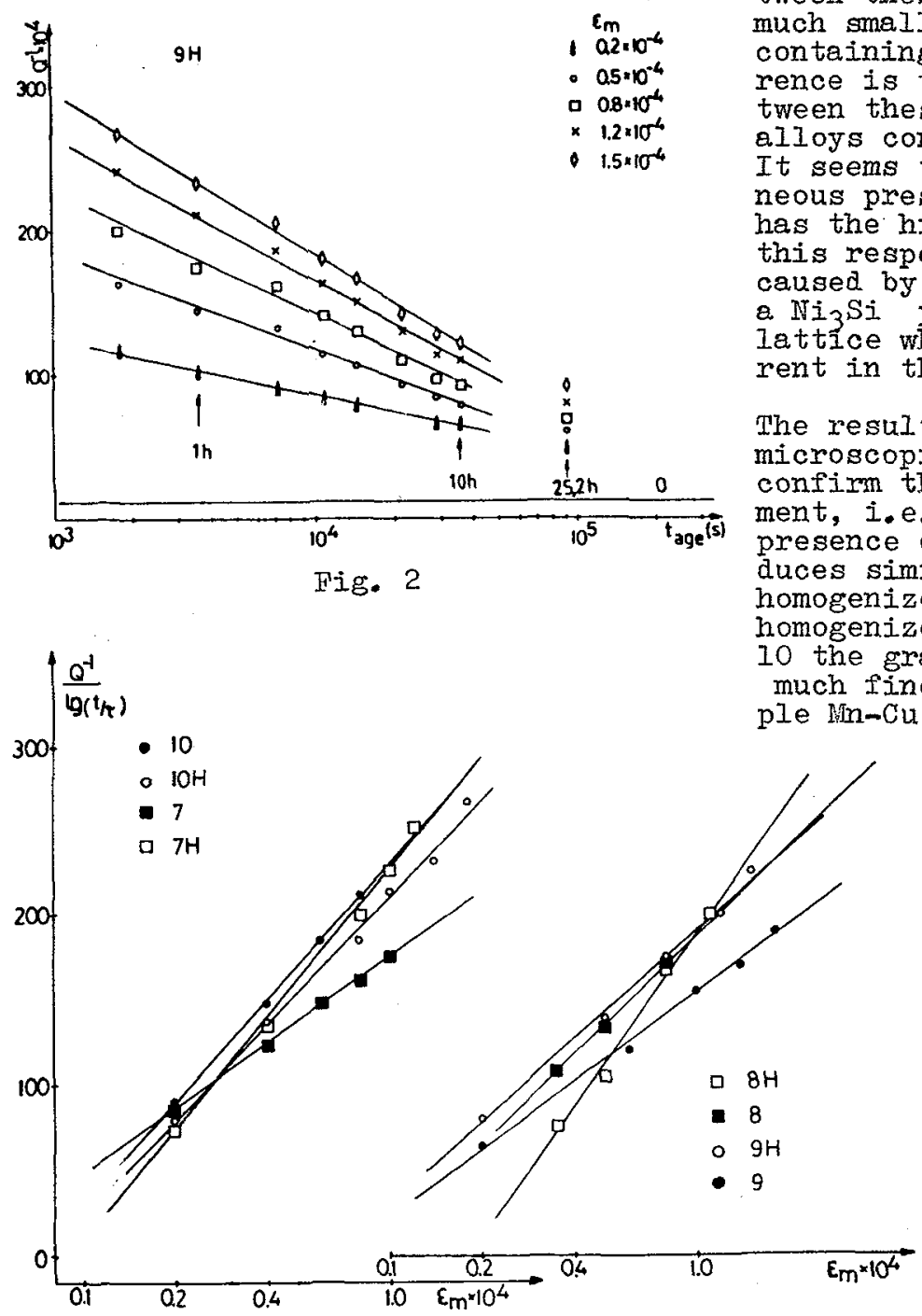
tween these two states is much smaller for alloys containing Si. The difference is the smallest between these two states for alloys containing $\mathrm{Ni}$ and $\mathrm{Si}$. It seems that the simultaneous presence of $N i$ and $S i$ has the highest effect in this respect. This could be caused by the formation of a $\mathrm{Ni}_{3} \mathrm{Si}$ phase with fcc lattice which can be coherent in the $\gamma \mathrm{K}-\mathrm{IIn}$ matrix.

The results of the electronmicroscopic investigations confirm the above establishment, i.e. the simultaneous presence of $\mathrm{Ni}$ and $\mathrm{Si}$ produces similar states in the homogenized and in the not homogenized alloys. In alloy 10 the grain structure is much finer than in the sinple Min-cu alloy. 
The $Q^{-I_{V s}}$ log tage plots help in determining the validity limits of the connection between the studied parameters. The amplitude dependence of the IF hold off below a definite value and the IF becomes constant. All straight lines in Fig. 2 /neglecting the last points/ can be extrapolated to the same toge $/ \approx 125 \mathrm{hrs} /$ except for the lowest $\mathcal{E}_{\text {m }}=0.2 \times 10^{-4}$. This fact can be caused by a change in the amplitude dependence. The decrease of the IF with increasing ageing times could refer to the change in the kinetics of the process. This can also be concluded from the fact that at a relatively high ageing time /22 - 25 hours/ the points do not fit onto straight Iines.

If we plot the curves shown in Fig. I in a log - log scale /Fig. 4/ we receive parallel straight lines for shorter annealing times. For longer ageing times $/ 6$ hours/ the points belonging to low deformation amplitude give a part having lower slope. We observed essential dif-

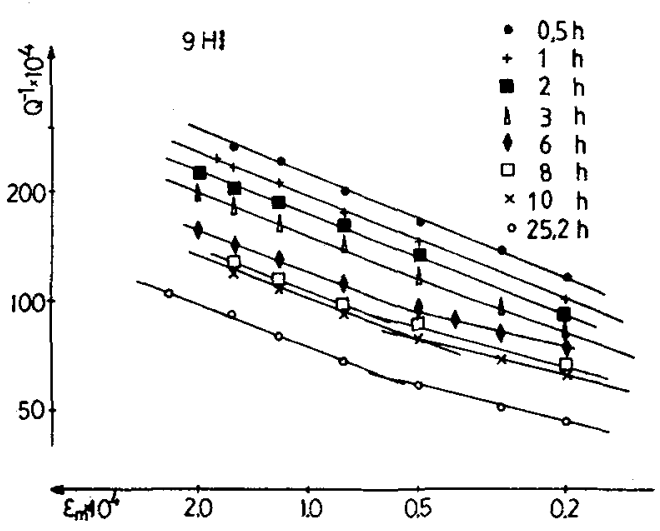

Fig. 4 ference between the homogenized and the non-homogenized states of alloy 7 , i.e. in the homogenized state we found a break after the first annealing $/ 0.5$ hour/ and on the contrary in $7 \mathrm{H}$ only after about 10 hours annealing. In all the other alloys in both states this breaking point appeared after an annealing for $6-8$ hours. On the basis of the development of the $\operatorname{HDCS}[3,6]$ we think that the decrease of the $A D I F$ can be connected with the increase of the amount of the $\alpha-i$ in phase.

It was found that the value of the IF and the ADIF did not change significally by sma.11 amounts of $\mathrm{Ni}$ and $\mathrm{Si}$. The rate of ADIF of lin-Cu high damping alloys was also similar in the four alloys. The simultaneous presence of $\mathrm{Ni}$ and $\mathrm{Si}$ produced a similar behaviour of IF in the homogenized and in the not homogenized states, and at the same time the IF of the alloys 7 and 8 differed essentielly in these two states.

Of course, a more exact picture can be build up when further results gained by other methods /microprobe, transmission eletcronmicroscopy/ are also available besides the IF measurements.

This research work was sponsored by Csepel Metal Works.

\section{References}

[I] STOKES H.J., HEWIN I.D., J. Inst.ifet. $89 / 1960-61 / 77$.

[2] GOODWIN R.J., Met.Sci. J. 2 /1968/ 121.

(3) BUTIER E.P.', KEIIY P.M., Trans.Met. Soc. AMm 242/1968/2099.

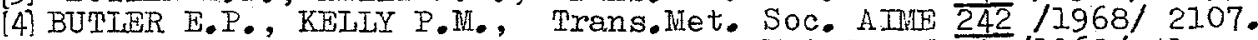

[5] BIRCHON D.;' BROMLEY D.E., HEALEY D., Met.Sci.J. $2 / 1968 / 41$.

[6] HEDLEY J.A., Met.SCi.J. 2 /1968/ I29.

[7] SMITH J.H., VANCE E.R., JAP 40 /1969/ 4853.

[8] HITTONO 0.', SA TOH T. KOYAMA $\frac{4}{Y}$, Trans.Jap.Inst.Met. $22 / 1981 / 225$.

(9) ZWICKER U., Z. Hetalikde 42 /1951/ 246.

[10] FAUSZTOV Ju. $K_{0}$, SULGA Ju. IT., RAHSTADT A.G., Metalloved, viszko dempf. szplav., Metaliurgija, Moszkva, 1980.

[1]] NOWICK A.S., BERRY B.S., Anelastic Relaxation in Crystalline

[12] BÖHÖNYEI A.,private communication. 